\title{
NAUCZYCIELSKI OBRAZ MŁODSZEGO UCZNIA NA PROGU CZWARTEJ KLASY
}

\begin{abstract}
Streszczenie: W artykule zaprezentowano wyniki badań fenomenograficznych, których przedmiotem są oczekiwania polonistów wobec ucznia w młodszym wieku, rozpoczynającego edukację w systemie przedmiotowym. Celem badania było dotarcie do przyjętego przez respondentki obrazu ucznia, będącego elementem ich indywidualnych teorii nauczycielskich, przekładającym się na praktykę nauczycielską, warunkującą adaptację czwartoklasistów, którzy w wieku sześciu lat rozpoczęli naukę w szkole. Przedstawione wyniki badań wskazują na to, że na obraz ucznia klasy IV - bez względu na wiek - składają się jego braki, których uzupełnianie będzie zadaniem nauczycieli. Wyniki badań ujawniają również, że obniżenie wieku czwartoklasisty wzmaga tendencję usilnego postrzegania ucznia przez pryzmat jego niedoskonałości.
\end{abstract}

Słowa kluczowe: obraz ucznia; edukacja wczesnoszkolna; edukacja przedmiotowa; młodszy wiek; model deficytów.

\section{Wprowadzenie}

Barbara Smolińska-Theiss (2014, s. 59) w swoim studium nad dzieckiem i dzieciństwem podkreśla rolę szkoły w pielęgnowaniu modelu dziecka w roli ucznia. Słusznie wskazuje na wymuszający charakter oddziaływań szkolnych na zachowanie dziecka. Siła szkoły polega na konserwowaniu modelu ucznia „na miarę”, sprawia, jak zauważa autorka, że staje się ona jego fundamentem lub reliktem.

W przyjętej w tym artykule perspektywie opisany obraz ucznia stanowi o „urządzeniu" dziecka w roli ucznia, odzwierciedla społeczno-kulturowe oczekiwania wobec niego i ukazuje rolę nauczyciela w ich realizowaniu. Pozwala odpowiedzieć na pytania, jakiego ucznia oczekuje szkoła i jakich wysiłków dokonuje, aby

* Dr Monika Kupiec, Akademia Pedagogiki Specjalnej im. M. Grzegorzewskiej w Warszawie, Instytut Wspomagania Rozwoju Człowieka i Edukacji; e-mail: mkupiec@aps.edu.pl. 
skonstruować jego rolę „na miarę” swoich oczekiwań, których nauczyciel jest bezpośrednim realizatorem oraz czy młodszy wiek dziecka różnicuje owe oczekiwania.

Wiek ucznia, jako podstawowa kategoria analizy i interpretacji wyników w tym artykule, zasadniczo stanowi punkt wyjścia do ukazania sposobów postrzegania zasobów dziecka, od których ostatecznie zależy konstruowanie warunków adaptacji - wchodzenie dziecka w nową rolę ucznia edukacji przedmiotowej bez względu na wiek.

Zjawisko przekraczania drugiego progu edukacyjnego było w ostatnich latach tematem dyskusji toczących się w różnych gremiach i instytucjach, wzbudzało zainteresowanie nauczycieli i rodziców dzieci kończących edukację wczesnoszkolną, ze względu na dwukrotne zmiany ministerialnych decyzji w sprawie wieku rozpoczynania realizacji obowiązku szkolnego. Jak pokazują badania Renaty Michalak (2013, s. 317), najczęściej uruchamiane przez czwartoklasistów strategie adaptacyjne do warunków edukacji przedmiotowej są oparte na lęku. Wysiłki szkoły we wprowadzaniu dziecka do nowej roli ucznia w edukacji przedmiotowej są zatem okupione przez nie strachem. Trzeba dodać, że to szerokie studium teoretyczno-empiryczne autorki nie uwzględnia kategorii młodszego wieku czwartoklasisty.

W niniejszym artykule zaprezentowano wyniki badań jakościowych, których przedmiotem są oczekiwania nauczycieli IV klasy wobec młodszego absolwenta wczesnej edukacji ${ }^{1}$.

Pytanie o sposób, w jaki nauczyciel definiuje swoje oczekiwania wobec dziecka - ucznia klasy IV, jego zasobów, cech, kompetencji - jest zasadniczo pytaniem o rozumienie roli praktyki nauczycielskiej oraz o jej praktykę w relacji z uczniem, w procesie jego adaptacji na drugim progu edukacyjnym. Próba odpowiedzi na pytanie, jak nauczyciel postrzega zasoby ucznia, którego dopiero bierze pod swoją opiekę, oraz o to, jak rozumie własne oddziaływania wobec dziecka, pozwala na ujawnienie przyjętego modelu ucznia, obrazu jego wiedzy i sposobu, w jaki się uczy. Kategoria wieku ucznia, rozpoczynającego naukę w klasie IV, staje się zatem pretekstem do zgromadzenia i opisu znaczeń, jakie nauczyciele nadają zasobom dziecka oraz własnym działaniom, a których celem jest wprowadzenie go w nową dla niego rolę ucznia w edukacji przedmiotowej.

\section{Indywidualne teorie nauczycielskie i ich znaczenie dla codziennej praktyki}

Obraz dziecka pokonującego próg klasy IV w oczach nauczyciela przedmiotu to jeden z elementów struktury jego teorii indywidualnej (Bałachowicz 2009, s. 155). Owe przekonania i oczekiwania, dotyczące m.in. sposobu, w jaki ono się uczy, jego rozwoju, uczniowskiej roli, sposobu aktywności na lekcji, nawiązywanych relacji

1 W artykule są prezentowane wyniki badań przeprowadzonych w związku z rozprawą doktorską autorki pt. Oczekiwania nauczycieli języka polskiego wobec ucznia na progu nauczania przedmiotowego, która została napisana pod kierunkiem prof. Józefy Bałachowicz. 
społecznych, nadadzą kierunek działań każdego nauczyciela, a te przełożą się na doświadczenia dziecka. Mnogość „stylów nauczania” nowych nauczycieli i ogromne zróżnicowanie w obrębie ich „względnie stałych sposobów działań edukacyjnych” (Bałachowicz 2009, s. 159) to codzienność każdego dziecka w klasie IV, kiedy dokonuje się złożony proces jego adaptacji do roli ucznia w systemie przedmiotowym.

Według Krzysztofa Polaka (1999), teoria indywidualna nauczyciela wykazuje dwojaki charakter: zawiera reprezentacje rzeczywistości szkolnej oraz sama jest instrumentem ich tworzenia i decyduje o sposobie doświadczania tej rzeczywistości. Teorie te posiadają aspekt poznawczo-orientacyjny, na który nakłada się aspekt emocjonalno-wartościujący. Według autora jest to typ wiedzy w działaniu, której nauczyciel używa podczas swojej pracy.

Przyjęty przez nauczyciela obraz dziecka w roli ucznia ma zatem zasadnicze znaczenie dla „określenia przez nauczyciela reguł interakcji i działania w środowisku edukacyjnym oraz planowania zajęć i ich realizacji” (Bałachowicz, Witkowska 2015, s. 191).

Stanisław Dylak wskazuje na rolę mechanizmu samospełniającej się przepowiedni w kształtowaniu i podtrzymywaniu indywidualnych teorii nauczycielskich, które „działają jak reflektory oświetlające tylko te obszary i zdarzenia, które chcemy zobaczyć" (2000, s. 178).

\section{Metodologia badań własnych}

Rozpoznanie oczekiwań nauczyciela wiązało się z próbą dotarcia do przyjętego przez niego obrazu młodszego ucznia, do tego elementu jego teorii indywidualnej, który przekłada się na praktykę nauczycielską warunkującą rodzaj tworzonego środowiska edukacyjnego, w jakim będzie odbywał się proces adaptacyjny uczniów klasy IV. Ważne więc jest ujawnienie tego, co jest w nim kolektywne, zwerbalizowane i wyłania się w wypowiedziach dotyczących działania nauczyciela wobec ucznia. Przedmiotem zainteresowań badawczych były nauczycielskie oczekiwania wobec ucznia rozpoczynającego klasę IV, koncentrujące się wokół kategorii wieku dziecka.

Przyjęta perspektywa fenomenograficzna, zakładająca jedność myślenia i działania, pozwoliła podjąć próbę ujawnienia, jak zaproszone do badania nauczycielki identyfikują własne spostrzeganie zasobów ucznia z codzienną praktyką edukacyjną.

Według Dariusza Kubinowskiego (2010, s. 194), fenomenografia opiera się na odkryciu, że każde zjawisko, koncepcja, zasada mogą być rozumiane przez ludzi w różny jakościowo sposób. Zakłada się jednak, że liczba konceptualizacji, interpretacji zjawiska jest ograniczona i nie ma potrzeby prowadzić badań z bardziej liczną grupą respondentek. Przyjęcie fenomenograficznej perspektywy badawczej umożliwia dotarcie do nauczycielskiego obrazu młodszego ucznia w klasie IV, który 
już ujawni pewną kolektywność sposobów myślenia o jego zasobach i kierunku działań edukacyjnych nauczycieli.

W niniejszym artykule zaprezentowano wyniki badań nad obrazem absolwenta edukacji wczesnoszkolnej w wypowiedziach nauczycielek języka polskiego w klasie IV, który wyłania się z określonych oczekiwań respondentek. Obraz absolwenta edukacji wczesnoszkolnej tworzą sensy wydobyte z deklarowanych oczekiwań oraz te zawarte w reprezentacjach dodatkowych, które towarzyszyły respondentkom $\mathrm{w}$ precyzowaniu swojego rozumienia badanego zjawiska.

W badaniach wzięło udział 27 nauczycielek języka polskiego, pracujących w klasach IV w szkołach na terenie miasta i gminy Wołomin w województwie mazowieckim. Większość badanych pełniła funkcję wychowawcy klasy od początku pracy zawodowej, dwie nauczycielki przyjęły ją po odbyciu stażu. Nauczycielki posiadały wymagane kwalifikacje zawodowe: tytuł magistra po pięcioletnich studiach filologii polskiej (17), uzupełniane kwalifikacje na trzysemestralnych studiach podyplomowych filologii polskiej, ukończone pięcioletnie studia na kierunkach pedagogicznych. Część badanych nauczycielek posiadających tytuł magistra filologii polskiej także ukończyła studia podyplomowe na kierunkach: logopedia (2), bibliotekarstwo (2), edukacja wczesnoszkolna (1). Jedna z badanych posiadała ty tuł magistra filologii polskiej i filologii angielskiej. Placówki, z których rekrutowały się uczestniczki badań, znajdowały się na terenach wiejskich (cztery szkoły) i miejskich (pięć szkół).

Prezentacji wyników badań dokonano w postaci siatek znaczeń nadawanych przez nauczycielki kategoriom związanym z postrzeganiem zasobów absolwenta edukacji wczesnoszkolnej w różnych obszarach jego funkcjonowania na początku klasy IV. Pole semantyczne badanych kategorii nazwano siatką znaczeń, gdyż łatwo dostrzec $\mathrm{w}$ niej przenikanie, powiązanie różnorodnych koncepcji, które w podejściu całościowym ujawniają pewne tendencje, ukryte w wypowiedziach nauczycielek. Ten sposób prezentacji wyników jest jednocześnie sposobem ich interpretacji. Siatka znaczeń akcentuje językowy walor tych wypowiedzi, ilustruje, jak różnie stylistycznie uczestniczki badań ujmują „swoje” doświadczanie wspólnej rzeczywistości. Takie ujęcie zjawiska w potocznym języku zdaje się szczególnie przybliżać ich wersję świata, do której podjęto próbę dotarcia. Łatwo w nich dostrzec podobny dobór słownictwa przez respondentki i jednocześnie uchwycić dominującą tendencję w sposobie określania, nazywania zasobów ucznia rozpoczynającego naukę w klasie IV.

Przyjętym kryterium uporządkowania materiału badawczego był sposób definiowania przez nauczycielki zasobów dziecka oraz sposobów własnego oddziaływania wobec niego. Nauczycielskie sposoby rozumienia danych kategorii zdają się niejednokrotnie wykraczać poza naukowe definicje, wzajemnie się przenikać, uzupełniać. 


\section{Wyniki badań własnych}

Nauczycielki posiadały doświadczenie w pracy z uczniem, kiedy to w zespole około 20-osobowym były również młodsze dzieci, od od jednego do trzech. W wypowiedziach zaproszonych do badań nauczycielek młodszy uczeń wyróżnia się na tle klasy złożonej ze starszych dzieci.

Tabela 1. Zasoby młodszego ucznia w wypowiedziach nauczycielek w klasie IV

„infantylne dziecko, ma swój świat”; „nie jest w stanie pojąc””; „najchętniej by się ciągle bawiły”; „mało dojrzałe, dziecinne”; „zaraz płacze, nie radzi sobie z emocjami”; „świat jej pisma jest światem bajki”; „będą wędrować w świat baśni częściej, odchodzić od tematu”; „obaj są słabi, ale ten młodszy szczególnie”; „nie odstają, są przygotowane, będą się uczyły tego samego”; „niedojrzałe emocjonalnie; mniejsza samodzielność, więcej problemów z emocjami”; „skupienie uwagi krótsze, problem z koncentracją”; „mniejsza wiedza o świecie”; „wolniejsze tempo pracy”; „bardzo wolne tempo pracy”; „uwaga i koncentracja dziecka będzie obniżona”; „im w głowie jeszcze zabawa, a nie obowiązki”; „inaczej postrzega sprawę obowiązku, czasu pracy”; „większa liczba dzieci z nieopanowanym czytaniem”; "rozumienie tekstu gorsze, gubią sens wypowiedzi”; „to, co mówią jest niedopasowane do reszty klasy”; „większy problem z czytaniem lektur, nie wszystkie będą gotowe przeczytać w całości i jeszcze zrozumieć”; „dukających, głoskujących”; „będzie problem z grafią, utrzymaniem w liniaturze”; „grafia raczej obniżona"

Źródło: opracowanie własne.

Zasoby ucznia postrzegane są jako niewystarczające lub nieadekwatne. Nauczycielskie wypowiedzi koncentrują się wyraźnie na brakach w jego zasobach, które wpływają na jakość adaptacji czwartoklasisty w nowym środowisku uczenia się i nauczania. Uczeń młodszy nie spełnia oczekiwań w wielu obszarach jego funkcjonowania w roli ucznia klasy IV, tak jak jego starszy kolega. Jednak można zauważyć, że nauczycielki oceniają zasoby młodszego ucznia gorzej. Świadczą o tym takie wyrażenia, jak: „będą wędrować w świat baśni częściej”, „mniejsza samodzielność”, „więcej problemów z emocjami”, „skupienie uwagi krótsze”, „mniejsza wiedza o świecie”, „wolniejsze tempo pracy”, „większa liczba dzieci z nieopanowanym czytaniem”, „rozumienie tekstu gorsze”, „większy problem z czytaniem lektur".

A zatem wiek ucznia w myśleniu uczestniczek badań stanowi kryterium oceny jego zasobów: młodsze = gorsze: mniej wie, mniej rozumie, mniej doświadcza. W wypowiedziach nauczycieli niedojrzałość (bycie młodszym) dziecka ujawnia się w jego zetknięciu z nowymi wymaganiami, zasadami. Dominującym sposobem rozumienia dojrzałości przez nauczycielki jest posłuszeństwo, wiedza o tym, co należy robić, a czego nie oraz wiedza i wypełnianie tego, czego oczekują inni. Uczeń, który jest niedojrzały, jest dzieckiem, które robi to, co chce mimo wiedzy 
o oczekiwaniach otoczenia. Niedojrzałość młodszego dziecka ujawnia się np. podczas wypowiedzi - mówi to, co jemu się wydaje, nie mówi tak jak inni (starsi) lub reaguje płaczem na trudności. Wyraźnie widać, że oczekiwane tempo pracy na lekcji dotyczy samodzielnego obcowania ze słowem pisanym.

Tabela 2. Obraz niedojrzałego ucznia w młodszym wieku w wypowiedziach nauczycieli czwartoklasistów

\begin{tabular}{|c|}
\hline ny \\
\hline $\begin{array}{l}\text { „w innej klasie dziewczyna - jest rozbiegana, ta starsza to jej przeciwieństwo - jest } \\
\text { skupiona, wie, co ma robić”; „przyswojeniu wiedzy, umiejętności, wiadomości będą } \\
\text { trudności, systematyczność, dyscyplina będzie inna. Im w głowie jeszcze zabawa, a nie } \\
\text { obowiązki”; „miały w tym roku problem z ilością pracy, to będzie problem i dla młod- } \\
\text { szych dzieci; mniejsza samodzielność wynikająca z mniejszej dojrzałości”; „najchęt- } \\
\text { niej by się ciągle bawiły, mało dojrzałe, dziecinne” }\end{array}$ \\
\hline Młodszy uczeń jest infantylny \\
\hline $\begin{array}{l}\text { „będą węd rować w świat baśni częściej, odchodzić od tematu”; „dzieci młodsze gubią } \\
\text { sens wypowiedzi, to, co mówią, jest niedopasowane do reszty klasy”; „świetnie czyta, } \\
\text { dobrze pisze, opowiada świetnie, ale treść jest infantylna”; „mimo że ma wiedzę } \\
\text { o życiu, rozmawia o wszystkim, jest świadoma, ale świat jej pisma jest światem bajki, } \\
\text { baśni” }\end{array}$ \\
\hline Młodszy uczeń jest zbyt emocjonalny \\
\hline ie z emocjami”; „spowo- \\
\hline Młodszy uczeń jest nieskoncentror \\
\hline $\begin{array}{l}\text { „skupienie uwagi krótsze, [...] to będzie obszar chyba najbardziej różnicujący dzieci } \\
\text { młodsze i starsze”; „możliwość na krócej skupienia uwagi”; „będzie problem z koncen- } \\
\text { tracją”; „będzie różnica, bo w rozwoju dziecka rok to dużo, w koncentracji na lekcji”; } \\
\text { „myślę, że uwaga i koncentracja dziecka będzie obniżona” }\end{array}$ \\
\hline Młodszy \\
\hline $\begin{array}{l}\text { „Z racji wieku będziemy mniej wymagać [...], będzie większy rozdźwięk w klasie } \\
\text { między dziećmi, bardzo wolne tempo pracy”; „skoro teraz nie można wypracować } \\
\text { efektywnych metod czytania, to będzie gorzej”; „spodziewam się większej liczby dzieci } \\
\text { z nieopanowanym czytaniem i jeszcze wolniejszym tempem pracy”; „wydaje mi się, } \\
\text { że dzieciom będzie trudniej, czy one będą umiały od razu w IV klasie napisać opo- } \\
\text { wiadanie”; „będzie wolniejsze tempo pracy, technika czytania, grafia raczej obniżona, } \\
\text { większe rozbieżności w klasie”; „młodsze dzieci w IV klasie to porażka, będzie więcej } \\
\text { dzieci dukających, głoskujących, będzie problem z grafią, utrzymaniem w liniaturze” }\end{array}$ \\
\hline Młodszy uczeń ma mniejszą wiedzę \\
\hline „nawet teraz trzeba im czasem tłumac \\
\hline
\end{tabular}

Źródło: opracowanie własne. 
Na podstawie przytoczonych wypowiedzi można określić, jakich cech oczekują respondentki od ucznia, gwarantujących mu dobrą adaptację. Wyraźnie można dostrzec, że nauczycielskie oczekiwania koncentrują się wokół posłuszeństwa, obowiązkowości, samodzielności, powściągliwości i pracy w szybkim tempie.

Analiza wypowiedzi pozwala na wyodrębnienie trzech dominujących sposobów rozumienia działania nauczyciela wobec młodszego ucznia o niższych zasobach, uwzględniających jego braki i realizujących powyższe oczekiwania, które mają - w rozumieniu respondentek - sprzyjać dobrej adaptacji dziecka w roli ucznia klasy IV.

Tabela 3. Działanie nauczyciela wobec młodszego ucznia w wypowiedziach nauczycielek

\begin{tabular}{|l|}
\hline Obniżanie wymagań, ułatwianie \\
„Z racji wieku będziemy mniej wymagać”; „trzeba im tłumaczyć ten język”; „muszę \\
prościej kierować polecenia”; „będę musiała zmieniać polecenia, będę musiała więcej \\
sama im czytać, wyrozumiałość musi być”; „trzeba się zniżyć do ich poziomu, trzeba \\
się dostosować, będę musiała nagiąć metody pracy, będę musiała obniżyć poziom \\
wymagan””; „będę musiała mówić prostszym językiem”; „,nie będę wiedzy wymagać \\
natychmiast, trzeba zażartować, praca w grupie będzie wymagała większej koordy- \\
nacji nauczyciela, więcej interwencji, organizacji”; „podejście powinno być takie, że \\
powinnam zaplanować tak lekcje, żeby treści nie było dużo” \\
\hline Uatrakcyjnianie, urozmaicanie, aktywizowanie \\
„będziemy musieli poświęcić czas na zabawę”; „nie można wymagać zawsze przepi- \\
sywania”; „będę musiała więcej pracować na komputerze”; „będę musiała dużo czytać \\
[w klasie]”; „będę musiała się przeorganizować”; „trzeba będzie więcej czasu poświęcić \\
na przygotowanie pomocy”; „trzeba prowadzić rozmowy dowolne, tu coś musi się \\
dziać” \\
Działanie bez zmiany \\
\hline „będą musiały się w tym odnaleźć”; „będą musieli wdrożyć się do tego”; „będzie wy- \\
magało więcej pracy, będzie wymagało większego przemyślenia, jak można te dzieci \\
utrzymać w ławkach”; „stawiam im wysokie wymagania, nie chcę obniżać wymagan, \\
muszę realizować podstawę programową”; „muszę ich wdrożyć do pracy w szybkim \\
tempie, opieram się na wymaganiach podstawy programowej, materiał trzeba reali- \\
zować”; „podstawa programowa musi być zrealizowana, wymagań nie zmienię, bo to \\
będzie musiało być tak samo”
\end{tabular}

Źródło: opracowanie własne.

Powyższe znaczenia wskazują na nadawanie swojemu działaniu formy przymusu, wynikającego zarówno z wieku dziecka i formalnych wymagań wobec nauczyciela, który „musi” realizować podstawę programową, przygotować do sprawdzianu. Wyraźnie w rozumieniu uczestniczek badań niższe zasoby młodszego ucznia „zmuszają” nauczycielki do „obniżenia wymagań”, natomiast nauczycielskie zobowiązania wykluczają tę możliwość. Wypowiedzi ujawniają uwikłanie nauczycielek, które widzą potrzebę konkretnej zmiany sposobu pracy z młodszym 
dzieckiem (np. „będziemy musieli poświęcić czas na zabawę”) i mają świadomość, że "nie mogą" sobie na to pozwolić (np. „lekcja ma nie przebiegać na zabawie”; „praca w grupach by pozostała, gry językowe... dzieci to bardzo lubią, a czasu jest tak niewiele na to").

Powyższe wypowiedzi ukazują również pewnego rodzaju schizofreniczność w nauczycielskim postrzeganiu własnych oczekiwań wobec młodszego ucznia. Schizofreniczność postrzegania zasobów ucznia polega na niedostrzeganiu konsekwencji realizowania swoich oczekiwań. Z jednej bowiem strony nauczycielki jasno formułują, czego oczekują i jak to osiągną w pracy z dzieckiem, z drugiej bardzo krytycznie wartościują możliwe efekty takich oddziaływań. Ostatecznie zatem zasoby ucznia zawsze są postrzegane jako niewystarczające, niskie.

Tabela 4. Konflikt nauczycielskich oczekiwań względem zasobów ucznia i ich oceny

\begin{tabular}{|c|c|}
\hline $\begin{array}{l}\text { Oczekiwania nauczycieli } \\
\text { względem zasobów ucznia }\end{array}$ & Ocena zasobów ucznia \\
\hline $\begin{array}{l}\text { - szybkie tempo pisania (pracy) } \\
\text { „tempo - dobrze by było, żeby było szyb- } \\
\text { sze, muszą pisać szybciej” }\end{array}$ & $\begin{array}{l}\text { - brak estetyki pisma } \\
\text { „pismo zmienia się na niechlujne, } \\
\text { niestaranne” }\end{array}$ \\
\hline $\begin{array}{l}\text { - zadawanie pytań } \\
\text { „jest aktywny - pyta, udziela odpowiedzi, } \\
\text { ma być na zasadzie dialogu, żywa lekcja”; } \\
\text { „jest śmiały - nie boi się zapytać, jeśli ma } \\
\text { wątpliwości, to powinien to sygnalizo- } \\
\text { wać”; „dobrze, gdy zadają pytania, dużo } \\
\text { pytań”; „nie lubię lekcji wykładowych, } \\
\text { kiedy ja mówię, oni zadają pytania, wiem, } \\
\text { co rozumieją, czego nie wiedzą”; „jestem } \\
\text { do ich dyspozycji, że można mnie zawsze } \\
\text { zapytać” }\end{array}$ & $\begin{array}{l}\text { - zadawanie zbyt wielu pytań } \\
\text { „pytają mnie po } 50 \text { razy, co było, mogą } \\
\text { się dopytywać, ale już w marcu mnie to } \\
\text { irytuje”; „denerwują mnie pytania typu, } \\
\text { jaki będzie temat, zalewanie pytaniami”; } \\
\text { „funkcjonowali dziecięco, o wszystko } \\
\text { pytali” }\end{array}$ \\
\hline $\begin{array}{l}\text { - praca w bezruchu i ciszy } \\
\text { „nie mam kłopotów z dyscypliną, siedzą } \\
\text { cicho”, „mają problem z wysiedzeniem } \\
\text { na lekcji”, „nie mogą usiedzieć w miejscu, } \\
\text { usadzam ich po okresie swobody według } \\
\text { mojego uznania”, „powtarza im się, że nie } \\
\text { wolno wstawać”, „przychodzą i skarżą”, } \\
\text { „przychodzi do mnie i mówi”, „idealne - } \\
\text { żadne nie podejdzie” }\end{array}$ & $\begin{array}{l}\text { - brak aktywności, problemy } \\
\text { z „koncentracją” } \\
\text { „dekoncentracja jest wielka, interesuje ich } \\
\text { to, co za oknem”; „problemy z koncen- } \\
\text { tracją, tylko myślą, żeby na dwór, nie są } \\
\text { zainteresowane” }\end{array}$ \\
\hline
\end{tabular}




\begin{tabular}{|l|l|}
\hline \multicolumn{1}{|c|}{\begin{tabular}{c}
\multicolumn{1}{|c|}{ Oczekiwania nauczycieli } \\
względem zasobów ucznia
\end{tabular}} & \multicolumn{1}{c|}{ Ocena zasobów ucznia } \\
\hline $\begin{array}{l}\text { • podatność na kontrolę } \\
\text {,jak stoję i sobie opowiadamy, jak te } \\
\text { wypowiedzi mają wyglądać”; „stale muszą } \\
\text { być pod naszym nadzorem, dostosowują } \\
\text { się tylko pod naszą kontrolą"; ,jeśli przy- } \\
\text { chodzą i się skarżą, to ja muszę wiedzieć } \\
\text { wcześniej” }\end{array}$ & $\begin{array}{l}\text { • brak samodzielności } \\
\text { "piszą zbyt krótko, oczekują konkretnej } \\
\text { instrukcji, pytają, na ile mają napisać”; } \\
\text { ciągle trzeba czymś interesować, bo } \\
\text { one nie potrafią same czymś się zająć na } \\
\text { chwilę, muszą być ciągle zajmowane” }\end{array}$ \\
\hline
\end{tabular}

Źródło: opracowanie własne.

W postrzeganiu nauczycielek zmiany w nauczaniu młodszego ucznia miałyby polegać przede wszystkim na częstszym stosowaniu aktywnych sposobów nauczania. Znamienne jest, że aktywność ucznia jest w świadomości nauczycielek sposobem na „rozluźnienie”, a nie procesem uczenia się. Aktywność rozumiana jako urozmaicenie, atrakcja, która ma zatrzymać ucznia w ławce, pełni funkcje dyscyplinujące, nie jest utożsamiana z procesem uczenia się: „[...] wpleść elementy zabawy, oczywiście lekcja ma nie przebiegać na zabawie, ale jej elementy mogą być wykorzystywane - gry dydaktyczne, między wiadomości wplatać im gry"; „większa różnorodność ćwiczeń, żeby dzieci się nie nużyły, nie męczyły, żeby ich najdłużej przytrzymać”; „będzie wymagało większego przemyślenia, jak można te dzieci utrzymać w lawkach”; „tu ciągle musi być działanie, ta praca w grupach, coś organizować, co je utrzyma w zainteresowaniu, w centrum"; „sprawdzi się praca w grupie - to najważniejsza metoda, która ułatwi i zadanie będzie wykonane".

Wyraźnie respondentki postrzegają potrzebę większego wysiłku ze swojej strony, zatem aktywność leży po stronie nauczyciela, a nie ucznia, bardziej aktywny ma być nauczyciel, który ma zadanie pokazać, wystąpić, najlepiej w atrakcyjnej formie, $\mathrm{z}$ „pomocami” („Przy tych maluchach pomoce, pomoce, pomoce. Każda lekcja musi być wyzwaniem, bo nie wysiedzą 45 minut [...]”). Działanie nauczyciela zatem ma odtąd przypominać grę aktorską, a uczeń pełnić rolę widza siedzącego w ławce.

Wypowiedzi ujawniają, że nauczycielki dostrzegają wymóg „większej pracy” i „większego przemyślenia”, co wskazuje na to, że dotychczas nie było to dla nich koniecznością („Myślę, że będzie to inna praca. [...]”). Wypowiedzi ilustrują także, jak nauczycielki postrzegają swoje dotychczasowe sposoby pracy na lekcji w klasach IV. 
Tabela 5. Obraz dotychczasowego działania nauczyciela wobec uczniów IV klasy „metoda, że ja mówię, mówię, a wy słuchacie, słuchacie, odpada”; „nie można wymagać zawsze przepisywania itp., bo to będzie dla nich szokiem, więc dłużej będzie trwało ich przygotowanie, że od tej pory tak będzie wyglądała ich praca”; „więcej rzeczy pisać, mniej mówić, bo one zapamiętują lepiej wzrokowo”; „teksty krótsze do czytania, przepisywania”; „mniej będzie pisania w zeszytach”; „zamiast notatki, czytania lekcja na zasadzie doświadczenia, przedstawienia, dramy”; „korzystamy z tablicy interaktywnej, dzieciom się to podoba, żeby coś poklikały, zawsze to coś innego niż taka nudna lekcja - pisanie, czytanie”; „na pewno nie tak, że tu zeszyt, książka, wy sobie przepisujecie, pracujecie, tutaj tablica, kreda... tu ciągle musi być działanie"; "aktywne metody, a nie - czytasz, odpowiadasz”; „więcej metod aktywnych, aktywizujących [...] inaczej planować pracę, w odstępach, mniej pracy samodzielnej”; „nie wyobrażam sobie, żeby z tymi dziećmi zachować takie tempo pracy jak teraz. Metody aktywizujące są zawsze mile widziane i dzieci chętnie nimi pracują. Dużo modyfikowania, żeby dzieci lepiej się koncentrowały, pracować należy niekoniecznie w ławkach”; „lubią, jak im się czyta, więc będę musiała dużo czytać”; „wiadomo, że musi być ćwiczenie pisma, ale nie takie obszerne. Teraz opis zajmuje w IV klasie około strony, nie wiem, czy będziemy w stanie tyle zapisać, bo dzieci będą pisały wolniej, ale będziemy się starać”; „oglądanie tego, co dzieci same przyniosą z domu, w ten sposób jeszcze nie do końca z tym dzieciństwem rozstaną”; „nie da się $\mathbf{4 5}$ minut usiedzieć w lawce, w zupełnej koncentracji. Trzeba prowadzić rozmowy dowolne, wprowadzać bliższe treści, niezwiązane z przedmiotem... Może będziemy od tego wychodzić?"

Źródło: opracowanie własne.

Powyższe wypowiedzi ujawniają, że nauczanie w IV klasie oparte jest na:

- werbalnym przekazie nauczyciela;

- samotnym („samodzielnym”) kontakcie ze słowem pisanym (czytanie, pisanie);

- $\quad$ pracy w ławkach w większości czasu;

- treściach dalekich doświadczeniu uczniów;

- okazjonalnej („odświętnej”) aktywności uczniów;

- pisaniu, czytaniu (istotną cechą jest tempo pisania i czytania).

\section{Wnioski}

B. Smolińska-Theiss (2014, s. 59) określa charakter oddziaływań szkoły na zachowanie dziecka jako wymuszający. Siła szkoły, konserwująca model ucznia „na miarę", sprawia, jak zauważa autorka, że staje się ona fundamentem lub reliktem modelu dziecka $w$ roli ucznia.

W przyjętej w tym artykule perspektywie opisany obraz ucznia: jego wiedzy, sposobu, w jaki się uczy, a także dotychczasowego źródła jego zasobów - stanowi o „urządzeniu” dziecka w roli ucznia edukacji przedmiotowej, odzwierciedla społeczno-kulturowe oczekiwania wobec niego i ukazuje rolę nauczyciela w ich realizowaniu. Pozwala odpowiedzieć na pytanie, jakiego ucznia oczekuje szkoła 
i jakich wysiłków dokonuje, aby skonstruować jego rolę „na miarę” swoich oczekiwań. Analizowana w tym artykule kategoria wieku ucznia rozpoczynającego edukację przedmiotową stała się pretekstem do poszukiwania przyjętego obrazu dziecka w roli ucznia. Jest to obraz przytłaczający i rozczarowujący, skrojony nie na miarę współczesnych oczekiwań wobec szkoły jako środowiska wzrostu, rozwoju. Przyjęcie obrazu ucznia ubogiego w zasoby determinuje przedmiotowe oddziaływania wobec dziecka, a zatem przeczy wnoszonym od dawna postulatom, w których „dziecko jako aktor społeczny jest współcześnie rozumiane jako wyjątkowy, złożony i jednostkowy, niepowtarzalny podmiot, konstruujący swoją indywidualność i społeczne relacje we współpracy z innymi” (Adamek, Bałachowicz 2016, s. 23).

$\mathrm{Na}$ obraz czwartoklasisty - niezależnie od jego wieku - będą zatem składały się jego braki, których uzupełnianie (tym intensywniejsze, im młodszy jest uczeń) będzie zadaniem nauczycieli edukacji przedmiotowej. Przedstawione wyniki badań wskazują na tendencję usilnego konserwowania modelu deficytów, co wiąże się z koncepcją wychowania i stwarzania dziecku warunków społeczno-kulturowych polegających na akcentowaniu tego, czego mu brakuje, czego nie ma, a co mieć powinien, gdyż tego się oczekuje (Śliwerski 2007, s. 102-110).

Adamek i Bałachowicz proponują wprowadzenie metafory „bogatego dziecka”, wyrażającej „ogromny potencjał rozwojowy dziecka, jego możliwości poznawcze, aktywność i zdolność do tworzenia znaczeń i konstruowania kultury, tworzenia własnych teorii świata i teorii umysłu" (2016, s. 23-24). Według autorek działanie edukacyjne nauczyciela wobec dziecka bogatego w kompetencje jest jednoznaczne ze stwarzaniem mu najlepszych warunków dla jego rozwoju. W ten sposób respektuje się kulturowe i społeczne podstawy uczenia się, a więc wypełnia się podstawowy cel edukacji we współczesnym świecie, w którym panuje zmienność, wielość i różnorodność (Touraine 2013, s. 163-164).

Wyniki przedstawionych badań ukazują wiedzę nauczycieli dotyczącą podstawowych dla edukacji kategorii (wiedza ucznia, uczenie się i nauczanie) w bardzo niekorzystnym świetle. Jednak uchwycona w analizie schizofreniczność postrzegania zasobów dziecka ujawnia uwikłanie nauczycielskich oczekiwań, ponieważ choć kształtują się w złożonym procesie, to zachowują niezależny charakter, realizując się ostatecznie w bezpośredniej relacji z uczniem. Adaptacja ucznia klasy IV niezależnie od wieku będzie zatem przebiegać wyraźnie pod wpływem oczekiwań nauczycieli, niejednokrotnie sprzecznych, paradoksalnych, niemożliwych do zrealizowania.

Oczekiwania nauczyciela, koncentrujące się na brakach dzieci kończących edukację wczesnoszkolną, wpływają na sposób adaptacji uczniów, zwłaszcza na początku klasy IV oraz mają wpływ na poziom lęku, frustracji i bierności. Oczekiwania nauczycieli wobec czwartoklasistów na początku nauki stanowią barierę, które dla większości dzieci jest nie do pokonania i może zaważyć na edukacji szkolnej. Dla wielu uczniów - niezależnie od ich wieku - to środowisko „pozaszkolne” stanie się miejscem ich rozwoju, zwłaszcza w zakresie niedostrzeganego lub deprecjonowanego przez nauczycieli potencjału, a szkole przypadnie rola konserwowania obrazu ucznia, jaki nie istnieje. 


\title{
Bibliografia
}

Adamek I., Bałachowicz J. (2014). Kompetencje kreatywne nauczyciela wczesnej edukacji dziecka. Kraków: Wydawnictwo Impuls.

Adamek I., Bałachowicz J. (2016). Pomiędzy dwiema edukacjami. Dziecko/uczeń w czasach zmiany. Łódź: Wydawnictwo Naukowe WSP.

Bałachowicz J. (2009). Style działań edukacyjnych nauczycieli klas początkowych. Między uprzedmiotowieniem a podmiotowościa. Warszawa: Wydawnictwo Comandor, s. 155.

Bałachowicz J., Witkowska-Tomaszewska A. (2015). Edukacja wczesnoszkolna $w$ dyskursie podmiotowości. Studium teoretyczno-empiryczne. Warszawa: Wydawnictwo APS.

Dylak S. (2000). Nauczycielskie ideologie pedagogiczne a kształcenie nauczycieli. W: Pedagogika w pokoju nauczycielskim. Kruszewski K. (red.). Warszawa: WSiP.

Kubinowski D. (2010). Jakościowe badania pedagogiczne. Filozofia, metodyka, ewaluacja. Lublin: Wydawnictwo UMCS.

Michalak R. (2013). Dziecko u progu edukacji przedmiotowej. Studium teoretyczno-empiryczne. Poznań: Wydawnictwo Naukowe UAM.

Polak K. (1999). Indywidualne teorie nauczycieli: geneza, badanie, kształtowanie. Kraków: Wydawnictwo UJ.

Smolińska-Theiss B. (2014). Dzieciństwo jako status społeczny. Edukacyjne przywileje dzieci klasy średniej. Warszawa: Wydawnictwo APS.

Śliwerski B. (2007). Pedagogika dziecka. Studium pajdocentryzmu. Gdańsk: GWP. Touraine A. (2013). Po kryzysie. Warszawa: Oficyna Naukowa.

\section{A TEACHER'S PICTURE OF A YOUNGER STUDENT ON THE $4^{\mathrm{TH}}$ GRADE}

\begin{abstract}
This article presents the results of phenomenographic research, the subject of which are expectations teachers of Polish have towards younger student starting the second stage of education (grades 4-8). The aim of the study was to establish the image of the student adopted by the respondents, which is part of their individual teaching theories. This image translates into teaching practice that can condition the functioning of fourth grade students who started their education at the age of six. The presented research results indicate that the image of a 4 th grade student - regardless of their age - is made up of deficiencies that will be supplemented by teachers. The research results also reveal that lowering the 4 th grade age increases the tendency of perceiving the student through the prism of his imperfections.
\end{abstract}

Keywords: student image; early school education; subject education; younger age; deficit model. 